\title{
Olive mill wastewater effects on durum wheat crop attributes and soil microbial activities: A pilot study in Syria
}

\author{
Jehan Khalil $^{1} \cdot$ Hasan Habib $^{1} \cdot$ Michael Alabboud $^{2} \cdot$ Safwan $_{\text {Mohammed }}^{3}(\mathbb{C}$ \\ ${ }^{1}$ Faculty of Agricultural, Department of Soil Science, Damascus University, Damascus, Syria \\ ${ }^{2}$ College of Agriculture and Natural Resources, University of Tehran, Karaj, Iran \\ ${ }^{3}$ Faculty of Agricultural and Food Sciences and Environmental Management, Institute of Land Use, Technology and Regional Development, \\ University of Debrecen, Debrecen, Hungary
}

Received: 2 December 2020/Revised: 23 February 2021/Accepted: 1 March 2021/Published online: 21 March 2021

(C) The Author(s) 2021

\begin{abstract}
Olive mill wastewater is one of the environmental problems in semiarid regions. The main goals of this study were to investigate the impacts of different olive mill wastewater levels on durum wheat (Triticum aestivum var. Douma1) production and soil microbial activities (i.e., bacteria and fungi). A pot experiment was conducted during the growing seasons 2015/2017 to evaluate the effect of three levels of olive mill wastewater on both growth and productivity attributes of wheat. Vertisol soil samples were collected from southern Syria. Two months before wheat cultivation, three levels of olive mill wastewater: T5 $\left(5 \mathrm{~L} / \mathrm{m}^{2}\right)$, T10 $\left(10 \mathrm{~L} / \mathrm{m}^{2}\right)$ and T15 $(15 \mathrm{~L} / \mathrm{m}$ ${ }^{2}$ ) were added to pots filled with the collected soil samples. Also, a control (T0) free of olive mill wastewater was considered as a reference. Results showed a significant increase $(p<0.05)$ in germination rate $(\%)$, plant height $(\mathrm{cm})$, ear length $(\mathrm{cm})$, kernels number, kernels weight per ear $(\mathrm{g})$ and grain yield $\left(\mathrm{g} / \mathrm{m}^{2}\right)$ compared to control. However, T5 treatment did not induce a significant increase in terms of ear length, kernels weight per ear or yield (in the second season). On the other hand, T10 treatment had recorded the best results compared with the other two treatments (T5, T15). Similarly, the results showed a significant increase in the number of bacterial and fungi cells by increasing olive mill wastewater concentration. This research provides promising results toward using olive mill wastewater in an eco-friendly way under Syrian conditions.
\end{abstract}

Keywords Vertisol; olive wastewater - Triticum durum . Semiarid regions; food security $\cdot$ Mediterranean region

Safwan Mohammed

safwan@agr.unideb.hu

\section{Introduction}

The disposal of olive mill wastewater (OMWW) is considered one of the recurrent environmental problems related to the olive oil industry in the Mediterranean region such as Tunisia (S'habou et al. 2009; Sahraoui et al. 2014; Mekki et al. 2006a, b), Greece (Kavvadias et al. 2014; Gikas et al. 2018), Spain (Paredes et al. 1999; LozanoGarcía et al. 2011) and Italy (Sciarria et al. 2013). One ton of olives usually produces one/two tons of OMWW according to oil-extracting technology (traditional and continuous systems), since one $\mathrm{kg}$ of olive requires an additional $2 \mathrm{~L}$ of water in the continuous extraction systems (Lanciotti et al. 2005). Thus, serious environmental problems such as surface and groundwater body contamination, besides severe soil pollution, have been continuously noticed near production areas, which are usually agricultural lands (Zema et al. 2019; Paraskeva and Diamadopoulos 2006; Chaari et al. 2015).

A growing body of the literature has highlighted the possibilities of using OMWW in Mediterranean countries. One way is to spread it over agricultural lands as a secondary source for crop fertilization and soil amendment. For instance, after nine years of using three OMWW doses $\left(50,100\right.$ and $\left.200 \mathrm{~m}^{3} \cdot \mathrm{ha}^{-1}\right)$ in Tunisia, Chaari et al. (2015) recommended using OMWW in organic production although of its high phenolic compounds content. In Southern Italy, Zema et al. (2019) noticed a sudden decrease in soil infiltration after irrigation by OMWW, in contrast to a marked increase after three weeks of treatment. Other soil parameters such as aggregate stability and nutrient contents (i.e., organic matter, phosphorous, potassium) increased. On the contrary, Barbera et al. (2014) reported that OMWW had a negative impact on 
plant germination and plant root system. Thus, extra caution is required when applying OMWW due to its adverse side effects on soil-plant system such as toxicity toward plants and soil biota (Barbera et al. 2014; Zema et al. 2019). Other reports of OMWW possible implications and effects in the agricultural sector can be found in Table 1.

Syria is a Mediterranean country with more than 79,000 hectares of olive trees. This fact renders olive trees the third largest cultivated crop in terms of area and production after cereals and cotton (Mohammed et al. 2019). Notably, exporting olive oil contributes $1.5-3.5 \%$ of the national gross domestic product (GDP), with Syria ranking the sixth largest country in olive production worldwide (Mohammed et al. 2019). In recent years, the olive sector has witnessed significant development in terms of expanding cultivation area, number of trees and production, which has led to an increase in the amount of OMWW produced from the oil industry. In 2012, the total OMWW was estimated to be 1 million cubic meters, and this amount is expected to increase in the next few years as a result of the continued expansion of olive cultivation and the introduction of 2-3 million new trees yearly into the production cycle (CBS, 2012).

OMWW is a major environmental problem in Syria due to many reasons such as: (1) the immediate and random dumping of OMWW without a proper treatment, which leads to soil pollution and the degradation of its physical, chemical and biological characteristics; (2) OMWW usually reaches lakes, rivers and groundwater, rendering these water resources undrinkable and posing a significant threat to aquatic life, especially in the coastal part of Syria; and (3) since chlorine is used to purify water in Syria, it might interact with the high percentage of polyphenolic compounds in OMWW polluted water causing the toxic chlorophenol to be formulated. Such material is even more dangerous to human health than phenol (Takriti et al. 2009). In this sense, The Syrian Ministry of Agriculture and Agrarian Reform (MoAAR) passed the law No. 190/T of 2007, which aims to regulate the use of OMWW in agricultural lands between 50 and $80 \mathrm{~m}^{3} / \mathrm{ha}$ according to extraction method (traditional, centrifugal) (Mahmoud et al. 2012).

Few researches were carried out to investigate the impact of local OMWW on some soil properties and plant production. Mahmoud et al. (2012) noticed that long-term (15 years) irrigation with OMWW in south-western Syria affected the topsoil layer making it more fragmented and prone to preferential solute transport. Similarly, Hayfa et al. (2016) concluded that adding OMWW had significantly enhanced some soil properties (i.e., electrical conductivity; organic matter content, soil porosity, total $\mathrm{Cu}$ and total $\mathrm{Mn}$ ); and the quality of tomato fruit (Solanum lycopersicum) (i.e., dry matter; total dissolved solids).

The vertisol covers roughly 9\% of the Syrian land, while it dominates in some areas located to the northeast of the country near the Turkish-Iraqi borders in addition to Houran plain, the central region and the northwestern regions (Mohammed et al. 2020). Since this soil is the dominant type in the Syrian agricultural areas, the main goal of this research was to investigate the possible use of

Table 1 Implication of OMWW in the agricultural sector in different regions around the world

\begin{tabular}{|c|c|c|}
\hline Region & Reference & Impact \\
\hline $\begin{array}{l}\text { Southern } \\
\text { Spain }\end{array}$ & Paredes et al. (1999) & $\begin{array}{l}\text { OMWW and the sludges contain substantial quantities of nutrients compared with compost and } \\
\text { manures. It is essential to be characterized before usage for agricultural purposes }\end{array}$ \\
\hline $\begin{array}{l}\text { Southern } \\
\text { Spain }\end{array}$ & $\begin{array}{l}\text { Ramos-Cormenzana } \\
\text { et al. (1996) }\end{array}$ & Bacillus pumilus reduced the phenol content of OMWW \\
\hline Tunisia & Zouari \& Ellouz (1996) & Reduction of COD by $50 \%$ by using bacterial mixtures obtained from local area \\
\hline Tunisia & Hachicha et al. (2008) & $\begin{array}{l}\text { A mixture natural fertilizer between olive oil production process, OMWW and poultry manure } \\
\text { positively affected potato production }\end{array}$ \\
\hline $\begin{array}{l}\text { South- } \\
\text { western } \\
\text { Syria }\end{array}$ & Mahmoud et al. (2010) & $\begin{array}{l}\text { Direct implementation of OMWW, without any treatments, for } 15 \text {-year reduced soil hydraulic } \\
\text { conductivity, drainable porosity }(\Phi<30 \mu \mathrm{m}) \text {, and increased the susceptibility of groundwater } \\
\text { pollution }\end{array}$ \\
\hline Italy & Di Serio et al. (2008) & $\begin{array}{l}\text { Direct increase in soil respiration activity due to } 161 / \mathrm{mg} \text { of OMWW, which was highly correlated } \\
\text { with decomposition of OM }\end{array}$ \\
\hline- & Barbera et al. (2013) & $\begin{array}{l}\text { Adding OMWW to soil increase } \mathrm{C} / \mathrm{N} \text { ratio and inhabited mineralization due to limited } \mathrm{N} \text { sources in } \\
\text { the soil }\end{array}$ \\
\hline Tunisia & Mekki et al. (2009) & Recommended OMWW amendment before using for agricultural purpose or adding to soil \\
\hline Italy & Ferri et al. (2002) & $\begin{array}{l}\text { Spreading OMWW on Triticum durum field decreased plant number and badly affected the leaf area } \\
\text { index and reduced the total dry matter. Also, leaf was subjected to necrotic spots }(20-30 \%)\end{array}$ \\
\hline Morocco & $\begin{array}{l}\text { Hanifi \& El Hadrami } \\
\text { (2008) }\end{array}$ & $\begin{array}{l}\text { For Zea mais L, OMWW inhabited coleoptile elongation between } 32 \text { and } 74 \% \text { and radicle growth by } \\
84 \%\end{array}$ \\
\hline
\end{tabular}


OMWW in Vertisol for wheat production as a proposed solution to minimize the negative environmental impact of OMWW. The detailed goals were to (1) highlight the dynamic interaction between wheat production and three levels of OMWW in Vertisol and (2) investigate the impact of different levels of OMWW on soil microbiological activities.

\section{Materials and methods}

\subsection{Olive wastewater (OMWW) and soil samples}

Olive mill wastewater was collected from a local centrifugation-based system press located in Isim village in the city of Qatana (southern Syria; $25 \mathrm{Km}$ from Damascus). The collected OMWW samples were placed in 20-L plastic containers and stored at a low temperature to avoid chemical and biological transformations during the study period (2015-2017). Different physical and chemical properties were measured as follows: $\mathrm{pH}$ (Conyrrs 1988); EC (Jones, 2001); ash percentage (\%); water content (\%); organic matter content (Jone 2001); total nitrogen (Bremner 1996); total $\mathrm{P}, \mathrm{Ca}, \mathrm{Mg}, \mathrm{Na}$ and $\mathrm{K}$ (Jackson 1958); microelements and heavy metals (Jones, 2001); phenols (Lee et al., 2003); oil content (NAM 2010); COD and BOD (Muthuvel \& Udaasoorian, 1999) (Table 2).

Vertisol soil samples were collected from Al-Thahalla village, Suwayda governorate (southern Syria) and prepared for wheat plantation. It is worth mentioning that soil samples were analyzed before and after treatments (data not shown).

\subsection{Experimental design}

A completely randomized experiment was carried out in triplicates during two consecutive agricultural seasons of 2015-2016 and 2016-2017 (Fig. 1). For that, $4 \mathrm{~kg}$ of

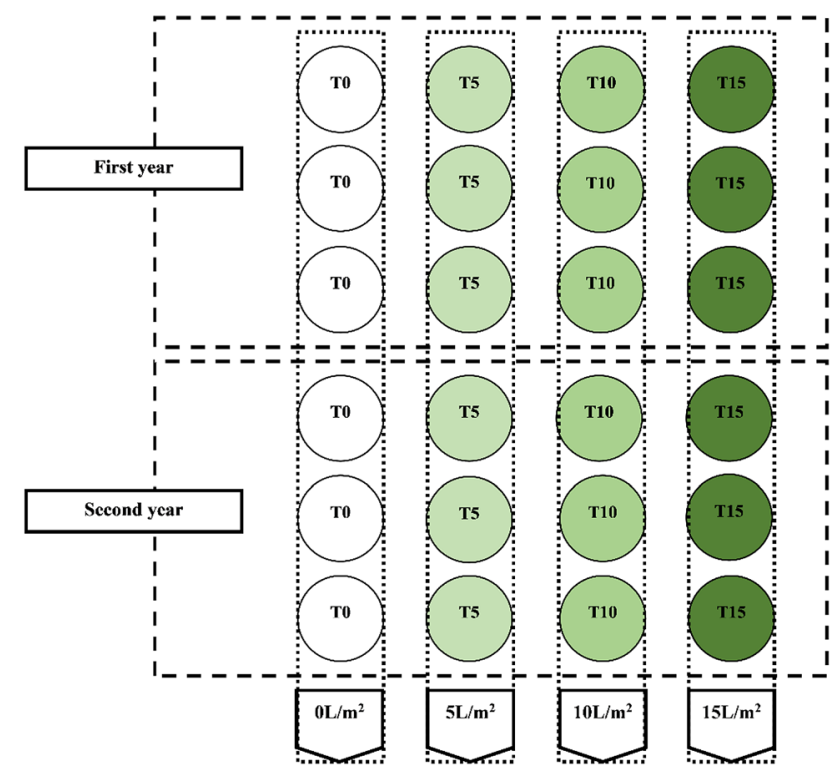

Fig. 1 Experimental design, first season (cultivation 4/12/2015, harvesting 16/6/2016) and second season (cultivation 9/12/2016, harvesting 20/6/2017)

homogeneous soil samples (vertisol) was distributed in plastic containers with an $18 \mathrm{~cm}$ diameter. OMWW was then added to the pots at three rates: $51 / \mathrm{m}^{2}$ (T5), $10 \mathrm{l} / \mathrm{m}^{2}$ (T10) and $15 \mathrm{l} / \mathrm{m}^{2}$ (T15). Taking into consideration the bulk density of vertisol samples $\left(1.13 \mathrm{~g} / \mathrm{cm}^{3}\right)$, a surface unit of $1 \mathrm{~m}^{3}$ and $0.3 \mathrm{~m}$ in depth would weigh $339 \mathrm{~kg}$. Thus, $4 \mathrm{~kg}$ of vertisol (each pot) will require 59, 118 and $117 \mathrm{ml}$ of OMWW for T5, T10 and T15 treatments, respectively. After addition, OMWW was thoroughly mixed the pots were left for two months prior to cultivation with regular watering ( $80 \%$ of field capacity) during this period, according to the recommendations of Ortiz-Garcia et al. (1997). By cultivation time, wheat kernels were added to the pots at a rate of 10 grains per pot and then were irrigated regularly to keep soil moisture around $80 \%$ of field capacity.
Table 2 Physicochemical properties of OMWW

\begin{tabular}{lrlr}
\hline OMWW properties & \multicolumn{1}{l}{ Value } & OMWW properties & \multicolumn{1}{c}{ Value } \\
\hline $\mathrm{pH}$ & $4.63 \pm 0.0648$ & $\mathrm{Fe}(\mathrm{ppm})$ & $18.30 \pm 1.5725$ \\
$\mathrm{EC}(\mathrm{dS} / \mathrm{m})$ & $8.82 \pm 0.0566$ & $\mathrm{Cu}(\mathrm{ppm})$ & $2.92 \pm 0.5617$ \\
Ash $(\%)$ & $0.80 \pm 0.0163$ & $\mathrm{Mn}(\mathrm{ppm})$ & $3.46 \pm 0.4114$ \\
Water $(\%)$ & $92.40 \pm 0.2007$ & $\mathrm{Zn}(\mathrm{ppm})$ & $2.83 \pm 0.0455$ \\
Organic matter $(\mathrm{g} / \mathrm{L})$ & $68.00 \pm 1.6330$ & $\mathrm{Cd}(\mathrm{ppm})$ & $0.12 \pm 0.0082$ \\
$\mathrm{~N}(\mathrm{ppm})$ & $812.63 \pm 4.2845$ & $\mathrm{~Pb}(\mathrm{ppm})$ & $0.56 \pm 0.0432$ \\
$\mathrm{P}(\mathrm{ppm})$ & $284.36 \pm 2.6426$ & Total $\mathrm{phenols}(\mathrm{g} / \mathrm{L})$ & $8.12 \pm 0.5146$ \\
$\mathrm{Ca}(\mathrm{ppm})$ & $151.32 \pm 2.6618$ & Oil $(\mathrm{g} / \mathrm{L})$ & $3.16 \pm 0.2406$ \\
$\mathrm{Mg}(\mathrm{ppm})$ & $78.41 \pm 1.6330$ & $\mathrm{COD}(\mathrm{g} / \mathrm{L})$ & $142.26 \pm 2.9334$ \\
$\mathrm{Na}(\mathrm{ppm})$ & $54.60 \pm 0.5666$ & $\mathrm{BOD}(\mathrm{g} / \mathrm{L})$ & $58.37 \pm 2.3088$ \\
$\mathrm{~K}(\mathrm{ppm})$ & $2231.00 \pm 21.6969$ & $\mathrm{COD} / \mathrm{BOD}$ & $2.43 \pm 0.0478$ \\
\hline
\end{tabular}




\subsection{Wheat morphological and yield traits}

Various morphological and yield-related traits of wheat plants were monitored. The germination percentage, plant height (at harvest), ear length (at harvest), the weight of grains per ear (post-harvest), the number of grains per ear (post-harvest) and yield per pot (post-harvest) were calculated as an average for the three replicates.

\subsection{Microbiological analysis}

Bacterial and fungal numbers in soil samples were evaluated using the volumetric dilution method until $10^{-5}$ for bacterial cultures and $10^{-4}$ for fungal cultures. Then, the dilutions were cultured in Petri dishes with three replicates for each dilution.

For bacterial culture, the soil extract environment was used ( $1 \mathrm{~kg}$ of soil $+1 \mathrm{~L}$ of distilled water) sterilized by autoclave and then filtered. The culture was supplemented with agar (at 1.5\%), and the $\mathrm{pH}$ degree was regulated to 7 using $0.1 \mathrm{M} \mathrm{HCl}$, since the original extract was alkaline. Three Petri dishes were cultivated from $10^{-5}$ dilution, where $1 \mathrm{ml}$ of this dilution was spread in each dish. Then, the culture environment was poured over it, stirred gently and then left to harden. After that, the dishes were placed inverted in the incubator and incubated at a temperature ranging between 30 and $35^{\circ} \mathrm{C}$.

As for fungi culture, Potato Dextrose Agar (PDA) environment was used. The $\mathrm{pH}$ was set to 6 . Three Petri dishes were cultivated from $10^{-4}$ dilution. One milliliter of this dilution was placed in each Petri dish, and the culture environment (PDA) was poured over it and left to harden. The dishes were incubated in an inverted position at a temperature of $25^{\circ} \mathrm{C}$ (Tepper et al. 1987).

Bacterial and fungal numbers were then calculated using the following formula, as suggested by Tepper et al. (1987):

$$
\mathrm{CFU}=\mathrm{ACN} / \mathrm{DF}
$$

where $\mathrm{CFU}$ is the bacterial/fungal cells number, $\mathrm{CAN}$ is the average cells count in the diluted culture, and DF is the dilution factor.

\subsection{Statistical analysis}

The experiment was conducted in a complete randomized design, with three replications per treatment. The normal distribution of the experimental data was evaluated by applying Shapiro-Wilk test. The treatment's means were compared using one-way ANOVA and Tukey's HSD $(p<0.05)$. Additionally, the correlation matrices between variables (i.e., germination (Ger.) in \%, plant height (Hig.) in $\mathrm{cm}$, ear length (Ear) in $\mathrm{cm}$, kernels number (Ker.) per ear, kernels weight (Ker.Wie) in g, yield in $\mathrm{g} / \mathrm{m}^{2}$ ) were plotted.

Statistical analysis was carried out using GenStat v-12 (Payne et al. 1987), SPSS software (v24; IBM, Chicago, IL, USA) (SPSS Inc. 1988), EViews software package (v10; New York, USA) (McCullough, 1999) and GraphPad Prism (v6; GraphPad Software, Inc).

\section{Results}

\subsection{OMWW and wheat growth}

\subsubsection{Germination percentage}

A significant increase in germination rates was observed under all treatments in comparison with control treatment. Although OMWW increased germination rates in the second season, this increase was only significant under T10 treatment, where the highest germination percentage was observed (Fig. 2a).

\subsubsection{Plant height}

The results obtained from both seasons showed that OMWW application had significantly increased plant height compared to the control treatment. The most significant effect in terms of plant height was observed in T10 treatment. Furthermore, it was noticed that plant height was significantly increased by increasing OMWW treatment from $\mathrm{T} 5$ to $\mathrm{T} 10$ and decreased again under T15, with this decrease being significant in the second season (Fig. 2c).

\subsubsection{Ear length}

Both T10 and T15 treatments induced a significant increase in ear length compared to the control and T5 treatments in both seasons. In contrast, no significant differences were found between the control and T5 treatment. Additionally, T10 resulted in the highest values of this attribute with $7.86 \mathrm{~cm}$ and $6.86 \mathrm{~cm}$ in both seasons, respectively, and significantly higher than those of T15 treatment (Fig. 2b).

\subsubsection{Kernels number and weight per ear}

Kernels' number per ear increased significantly under OMWW application when compared to the control treatment. Furthermore, significant differences were found between the three levels. The highest value was noticed under T10 treatment in the second season with 51.28 kernels per ear (Fig. 2d).

OMWW treatments showed a significant increase in kernels' weight per ear compared to the control sample. 
Fig. 2 Impact of OMWW treatments on studied parameters: a Ger. \%, b Hig. in $\mathrm{cm}$, $\mathbf{c}$ Ear in cm, $\mathbf{d}$ Ker.per ear, e Ker.Wie in $\mathrm{g}$, $\mathbf{f}$ yield in $\mathrm{g} / \mathrm{m}^{2}$ ). Columns with similar litters have no significant differences based on Tukey's HSD test $(p<0.05)$
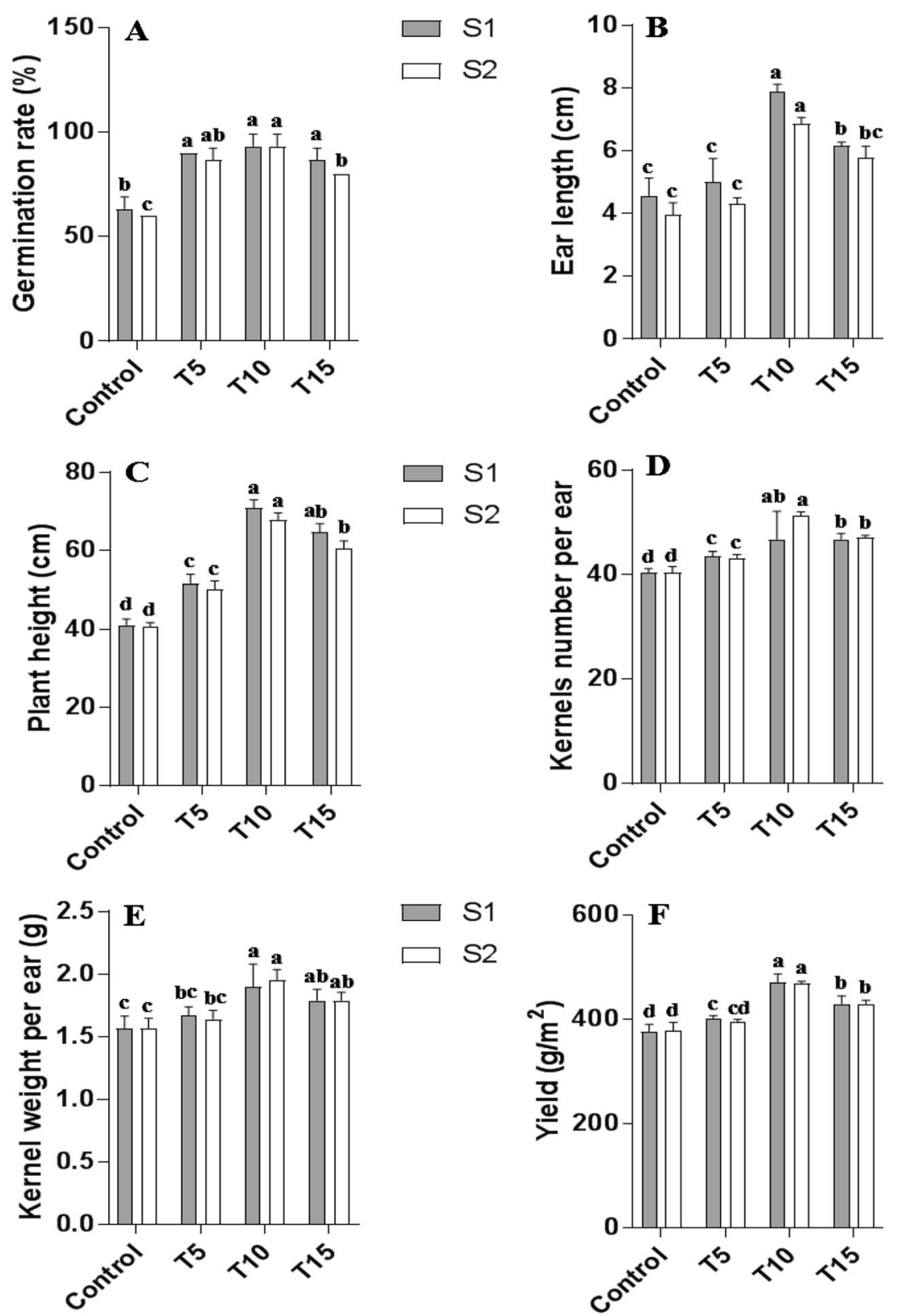

The highest recorded observations were under T10 treatment with $1.90 \mathrm{~g} / \mathrm{ear}$ and $1.95 \mathrm{~g} / \mathrm{ear}$ in the first and second seasons, respectively. Similar to ear length results, T5 treatment did not induce a significant increase in kernels' weight per ear when compared to the control (Fig. 2e).

\subsubsection{Yield}

The yield was calculated and expressed based on $\mathrm{m}^{2}$ basis. The results showed a significant increase in total yield compared to the control for T15, T10 and the first season under T5 treatment. The highest increase was recorded under T10 treatment with 24.94 and $23.84 \%$ yield increase in the first and second seasons, respectively. Simultaneously, the lowest increase was recorded under T5 treatment with only 6.37 and a $4.26 \%$ increase in the first and second seasons, respectively (Fig. 1f).

In this context, Fig. 3 depicts the correlation matrix between studied variables of wheat. Interestingly, a significant $(p<0.001)$ highly positive correlation was observed between all the studied variables, which revealed a positive impact of different treatments in wheat production. The highest correlations were $r_{\text {Hig. Vs. Yield }}(0.94$, $p<0.001)$ and $r$ Ear. Vs. Yield $(0.90, p<0.001)$, while the lowest correlations were $r_{\text {Ker. Vs. Ker.Wie. }}(0.62, p<0.001)$ and $r_{\text {Ger. Vs. Ker.Wie }}(0.64, p<0.001)$. Nonetheless, more 
Fig. 3 Correlation matrix between wheat studied variables

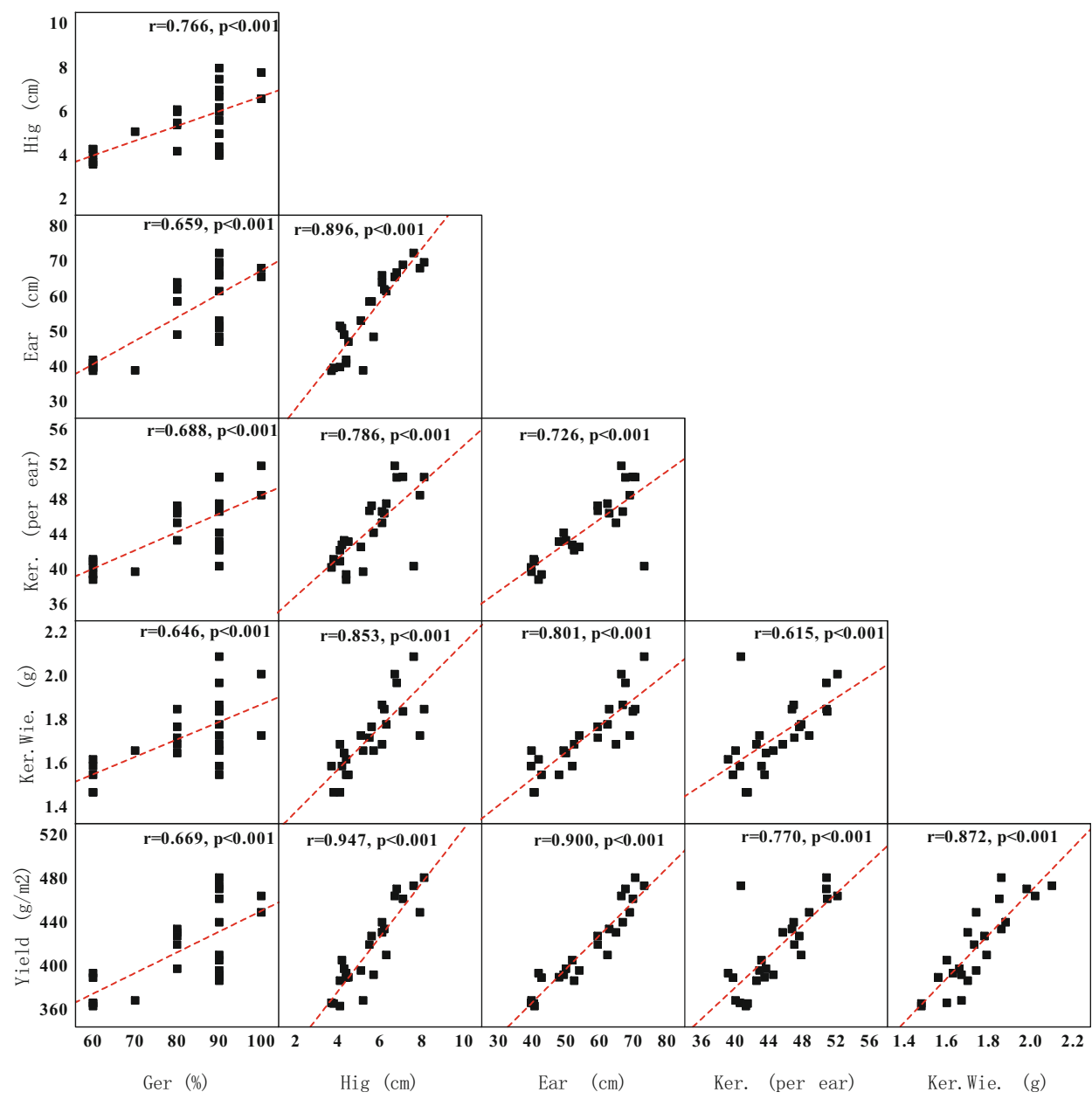

experiments should be conducted to verify the output of the correlation matrix.

\subsection{OMWW and microbiological activities}

\subsubsection{Bacterial count}

The highest bacterial count was recorded under T10 treatment in both seasons with 43.18 and $40.91 \mathrm{CFU} /$ $10^{-5} \mathrm{~g}$ soil. However, no significant differences were recorded between $\mathrm{T} 10$ and $\mathrm{T} 15$ treatments in the first season. The lowest observations were recorded in control in both seasons, which lead to the conclusion that olive wastewater treatment had increased the bacterial count in general, and this increase was significant starting from T5 treatment (Fig. 4a).

\subsubsection{Fungal count}

The statistical analysis results in both seasons indicated a significant increase in the number of fungi by each increase in the concentration of added olive wastewater treatments.
T15 treatment recorded the highest counts in both seasons with 11.58 and $11.21 \mathrm{CFU} / 10^{-4} \mathrm{~g}$ soil, respectively (Fig. 4b).

\section{Discussion}

The current results showed that OMWW treatment might induce an increase in kernel germination at any concentration (T5-T15). It was reported that the direct cultivation post-OMWW treatment without an induced bacteriological decomposition decreased the germination percentage in wheat (Casa et al. 2003) or inhibited germination even if diluted (Mekki et al. 2006a, b). Additionally, a decrease in tomato seed germination rate was observed after OMWW addition at rates of 40 and $80 \mathrm{~m}^{3} /$ ha (Piotrowska et al. 2006). This decrease was attributed to the increased phytotoxicity after OMWW addition, especially under higher rates $\left(80 \mathrm{~m}^{3} / \mathrm{ha}\right)$. However, it was apparent that 45 days of incubation were almost enough to restore normal germination rates under lower rates. The current study results of increased germination percentage under OMWW might be 
Fig. 4 Impact of OMWW treatments on microbiological activities: a bacterial count, b fungal count. Columns with similar litters have no significant differences based on Tukey's HSD test $(p<0.05)$
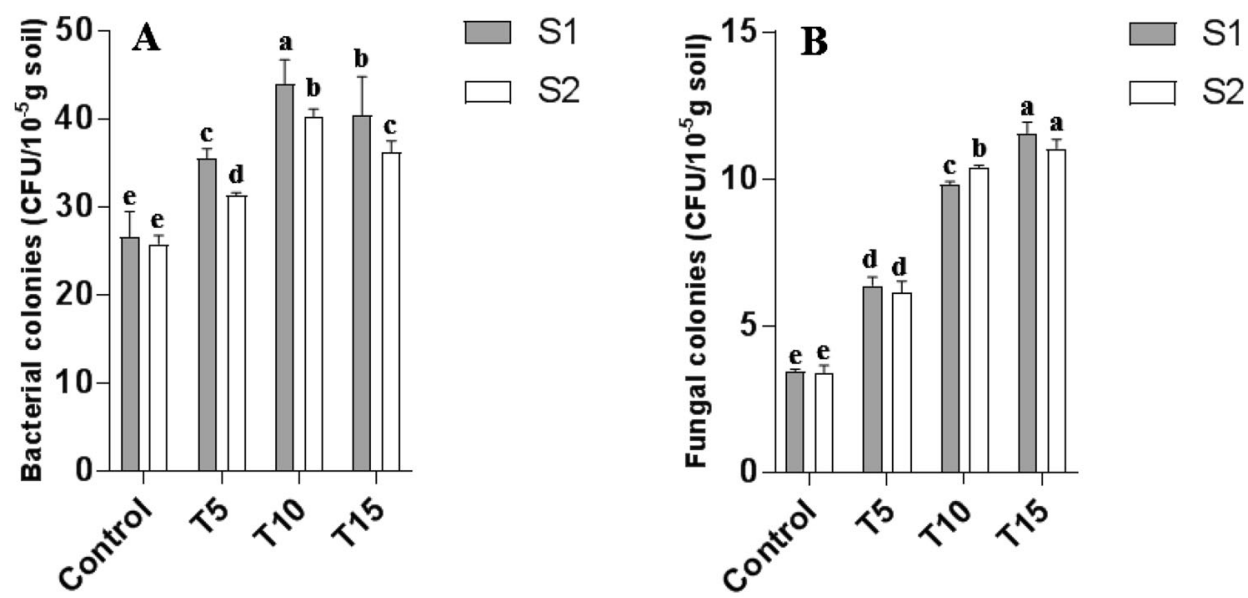

attributed to the decrease in the overall phytotoxicity after an incubation period of two months with an increase in germination assistant substances such as humic acids. Although humic acid content was not measured in the current work, other studies showed that OMWW has good composting potential (Madejón et al. 1998; Cigarra et al. 1999; Tomati et al. 1995). Consequently, humic acids resulted from OMWW application might stimulate enzyme systems in the kernel and, thus, provides the energy needed for the embryo during the transformation from the nonphotosynthetic phase to the autotrophic phase (Mekki et al. 2013). Therefore, a bacteriological decomposition is crucial after OMWW application.

The observed increase in plant height due to OMWW treatments was previously noted by (Alibrahim et al. 2008), who reported significant increases in wheat plant height under olive wastewater treatment of 5,10 and $20 \mathrm{~m}^{3} / 1000$ $\mathrm{m}^{2}$. Pomace treatment, which is another by-product of olive oil extraction, induced an increase in kernels weight and kernels number in the area unit (Brunetti et al. 2005), which is similar to the current observations.

The current increase in yield under OMWW treatments was expected due to the increase in both kernels number per ear and average kernel weight per ear under olive wastewater treatments. These results are similar and exceed those of Mekki et al. (2006a, 2006b), who reported a 5\% yield increase in wheat under olive wastewater treatment compared to the control sample as a result of the increase in both kernel weight and ears per plant.

Mechri et al. (2008); Saadi et al. (2013); and Mohawesh et al. (2019) reported that phenolic content was decreased after a period of adding OMWW, which might be the case in the current study due to the two-month waiting period. Therefore, the observed increase in the bacterial cell's numbers in all OMWW-treated soils was due to the decreased inhibitory effect of phenolic compounds accompanied by a high organic matter content, which plays an essential role in supplying the bacterial cells with the nutrients and energy needed for their activity. This observation corresponds with Piotrowska et al. (2006) and Badran (2011) reports of total bacterial numbers increase after a period of adding wastewater. On the other hand, the slight decrease in CFU under T15 treatment compared to T10 might be due to phenols exceeding a certain inhibitory threshold. Similarly, Naeb (2011) previously found that adding wastewater to the soil in large quantities can negatively affect the microbial activity and the processes of decomposition of organic matter in the soil due to the high percentage of phenolic substances in it, while the small quantities positively affect the activity of microorganisms in the soil.

As for fungal cell numbers after OMWW treatments. Naeb (2011) found a decrease in the number of fungi after adding wastewater to the soil at a rate of $\left(20 \mathrm{l} / \mathrm{m}^{2}\right) \mathrm{com}$ pared to adding it at a rate of $10 \mathrm{l} / \mathrm{m}^{2}$. This observation might be due to the wastewater phenolic compounds, sugars, fats and proteins, in addition to some aromatic compounds that inhibit the growth of these microorganisms (Tushan et al. 2010). However, the consistent increase in the current study might be due to the degradation of toxicity-inducing substances after the 2-month waiting period, similar to Zenjari et al. (2006).

\section{Conclusion}

In this research, vertisol was treated with three different levels of OMWW T5 $\left(5 \mathrm{~L} / \mathrm{m}^{2}\right), \mathrm{T} 10\left(10 \mathrm{~L} / \mathrm{m}^{2}\right)$ and T15 $\left(15 \mathrm{~L} / \mathrm{m}^{2}\right)$ and then planted with wheat for two successive seasons. Soil treatments of different levels of OMWW showed a significant effect on wheat growth and production. Both kernel germination and plant height increased with OMWW application compared with the control sample. Similarly, ear length, kernels number per ear and 
average kernel weight increased significantly. These results were a direct consequence of enhancing the physicochemical properties of soil. Notably, our results reveal that $\mathrm{T} 10\left(10 \mathrm{~L} / \mathrm{m}^{2}\right)$ was superior among other treatments. Thus, this amount of OMWW $\left(10 \mathrm{~L} / \mathrm{m}^{2}\right)$ could be recommended for agricultural application.

The current results on wheat production promising and could render the reported treatment as a sustainable solution for OMWW problem in Syria. However, further investigation should be conducted under different agroclimatic zones, various pre-application period or bacterial degradation treatments to ensure the positive impact of OMWW under Syrian conditions, especially in vertisol.

Acknowledgments The authors grateful for Damascus and Debrecen Universities for their unlimited support. Authors also thank the anonymous reviewers and editorial board for their constructive comments for improving the manuscript.

Funding Open access funding provided by University of Debrecen.

\section{Declarations}

Conflict of interest The author declares that they have no conflict of interest.

Open Access This article is licensed under a Creative Commons Attribution 4.0 International License, which permits use, sharing, adaptation, distribution and reproduction in any medium or format, as long as you give appropriate credit to the original author(s) and the source, provide a link to the Creative Commons licence, and indicate if changes were made. The images or other third party material in this article are included in the article's Creative Commons licence, unless indicated otherwise in a credit line to the material. If material is not included in the article's Creative Commons licence and your intended use is not permitted by statutory regulation or exceeds the permitted use, you will need to obtain permission directly from the copyright holder. To view a copy of this licence, visit http://creativecommons. org/licenses/by/4.0/.

\section{References}

Alibrahim A, Al-Nabil H, Ghadry M (2008) The effect of using olive squeezing water in agricultural lands cultivated with wheat on soil properties and production. Agricultural Research Center, Idlib, Syria. (in Arabic)

Badran A (2011) The effect of adding different levels of OMWW on some soil properties of cultivated citrus field. PhD Thesis, Faculty of Agriculture, Tishreen University. (in Arabic)

Barbera AC, Maucieri C, Cavallaro V, Ioppolo A, Spagna G (2013) Effects of spreading olive mill wastewater on soil properties and crops, a review. Agric Water Manag 119:43-53

Barbera AC, Maucieri C, Ioppolo A, Milani M, Cavallaro V (2014) Effects of olive mill wastewater physico-chemical treatments on polyphenol abatement and Italian ryegrass (Lolium multiflorum Lam.) germinability. Water Res 52:275-281

Bremner JM (1996) Nitrogen-total. Methods of Soil Analysis: Part 3 Chemical Methods 5:1085-1121

Brunetti G, Plaza C, Senesi N (2005) Olive pomace amendment in Mediterranean conditions: effect on soil and humic acid properties and wheat (Triticum turgidum L.) yield. J agric food chem 53(17):6730-6737

Casa R, D’Annibale A, Pieruccetti F, Stazi SR, Sermanni GG, Cascio BL (2003) Reduction of the phenolic components in olive-mill wastewater by an enzymatic treatment and its impact on durum wheat (Triticum durum Desf.) germinability. Chemosphere 50(8):959-966

CBS: Central Bureau of Statistics. National report for Syrian resources. Damascus, Syria. http://cbssyr.sy/index-EN.htm

Cegarra, J.; Amor, J.B.; Gonzálvez, J.; Bernal, M.P.; Roig, A. Characteristics of a new solid olive-mill-byproduct ("alperujo") and its suitability for composting. In Proceedings of the International Composting Symposium, Halifax/Dartmouth, NS, Canada, 19-23 September 1999; Volume 1, pp. 124-140.

Chaari L, Elloumi N, Mseddi S, Gargouri K, Rouina BB, Mechichi T, Kallel M (2015) Changes in soil macronutrients after a long-term application of olive mill wastewater. J Agric Chem Environ 4(01): 1

Conyers MK, Davey BG (1988) Observations on some routine methods for soil $\mathrm{pH}$ determination. Soil Sci 145(1):29-36

Di Serio MG, Lanza B, Mucciarella MR, Russi F, Iannucci E, Marfisi P, Madeo A (2008) Effects of olive mill wastewater spreading on the physico-chemical and microbiological characteristics of soil. Int Biodeterior Biodegradation 62(4):403-407

Ferri, D., Convertini, G., Montemurro, F., Rinaldi, M., \& Rana, G. (2002). Olive wastes spreading in Southern Italy: Effects on crops and soil. In Proceedings of 12th International Soil Conservation Conference,(ISCO): Sustainable Utilization of Global Soil and Water Resources (pp. 593-600).

Garcia-Ortiz, A., Beltrán, G., Uceda, M., Hermoso, M., González, P., Ordóñez, R., \& Giráldez, J. V. (1997 September). Vegetation water (alpechin) application effects on soils and plants. In III International Symposium on Olive Growing 474 (pp. 749-752).

Gikas GD, Tsakmakis ID, Tsihrintzis VA (2018) Hybrid natural systems for treatment of olive mill wastewater. J Chem Technol Biotechnol 93(3):800-809

GraphPad Prism (Version 6) [Computer software]. La Jolla, CA: GraphPad Software, Inc. Retrieved from http://www.graphpad. $\mathrm{com} / \mathrm{scientific-software/prism/}$

Hachicha S, Sallemi F, Medhioub K, Hachicha R, Ammar E (2008) Quality assessment of composts prepared with olive mill wastewater and agricultural wastes. Waste Manage 28(12):2593-2603

Hanifi S, El Hadrami I (2008) Phytotoxicity and fertilising potential of olive mill wastewaters for maize cultivation. Agron Sustain Dev 28(2):313-319

Hayfa S, Ahmad E, Albudi M, kashour B. (2016) The effect of Olive Mill wastewater (OMWW) on some soil properties and its content of some micro elements and the quality of tomato plant grown in the green house. Albath journal 38(46):182-153

Jackson ML (1958) Soil chemical analysis prentice Hall. Inc. Englewood Cliffs, NJ 498:183-204

Jones JB Jr (2001) Laboratory guide for conducting soil tests and plant analysis. CRC Press

Kavvadias V, Doula M, Theocharopoulos S (2014) Long-term effects on soil of the disposal of olive mill waste waters (OMW). Environ Forensics 15(1):37-51

Lanciotti R, Gianotti A, Baldi D, Angrisani R, Suzzi G, Mastrocola D, Guerzoni ME (2005) Use of Yarrowia lipolytica strains for the treatment of olive mill wastewater. Biores Technol 96(3):317-322

Lee KW, Kim YJ, Lee HJ, Lee CY (2003) Cocoa has more phenolic phytochemicals and a higher antioxidant capacity than teas and red wine. J Agric Food Chem 51(25):7292-7295

Lozano-García B, Parras-Alcántara L, De Albornoz MDTC (2011) Effects of oil mill wastes on surface soil properties, runoff and 
soil losses in traditional olive groves in southern Spain. CATENA 85(3):187-193

Madejón E, Galli E, Tomati U (1998) Composting of wastes produced by low water consuming olive mill technology. Agrochimica 42:135-146

Mahmoud M, Janssen M, Haboub N, Nassour A, Lennartz B (2010) The impact of olive mill wastewater application on flow and transport properties in soils. Soil Tillage Res 107(1):36-41

Mahmoud M, Janssen M, Peth S, Horn R, Lennartz B (2012) Longterm impact of irrigation with olive mill wastewater on aggregate properties in the top soil. Soil Tillage Res 124:24-31

McCullough BD (1999) . Econometric Software Reliability: EViews, LIMDEP, SHAZAM and TSP; JSTOR: New York, NY, USA,

Mechri B, Mariem FB, Baham M, Elhadj SB, Hammami M (2008) Change in soil properties and the soil microbial community following land spreading of olive mill wastewater affects olive trees key physiological parameters and the abundance of arbuscular mycorrhizal fungi. Soil Biol Biochem 40(1):152-161

Mekki A, Dhouib A, Sayadi S (2006a) Changes in microbial and soil properties following amendment with treated and untreated olive mill wastewater. Microbiol Res 161(2):93-101

Mekki A, Dhouib A, Sayadi S (2009) Evolution of several soil properties following amendment with olive mill wastewater. Prog Nat Sci 19(11):1515-1521

Mekki A, Dhouib A, Sayadi S (2013) Effects of olive mill wastewater application on soil properties and plants growth. Int J Recycl Org Waste Agric 2(1): 15

Mekki A, Dhouib A, Aloui F, Sayadi S (2006b) Olive wastewater as an ecological fertiliser. Agron Sustain Dev. 26(1):61-67

Mohammed SA, Alkerdi A, Nagy J, Harsányi E (2019) Syrian crisis repercussions on the agricultural sector: Case study of wheat, cotton and olives. Reg Sci Policy Pract 12(3):519-537

Mohammed S, Khallouf A, Kiwan S, Alhenawi S, Ali H, Harsányi E, Habib H (2020) Characterization of major soil orders in Syria. Eurasian Soil Sci 53:420-429

Mohawesh O, Al-Hamaiedeh H, Albalasmeh A, Qaraleh S, Haddadin M (2019) Effect of olive mill wastewater (OMW) application on soil properties and wheat growth performance under rain-fed conditions. Water Air Soil Pollut 230(7):160

Muthuvel P, Udayasoorian C (1999) Soil, plant, water and agrochemical analysis. Tamil Nadu Agricultural University, Coimbatore, India

Naeb H. 2011. The effect of adding different level of OMWW on some chemical, physical, biological and productive properties of soil. PhD Thesis, Faculty of Agriculture, Tishreen University. (in Arabic)

NAM: national analysis manual. (2010). Damascus, Syria

Paraskeva P, Diamadopoulos E (2006) Technologies for olive mill wastewater (OMW) treatment: a review. J Chem Technol Biotechnol: Int Res Process Environ Clean Technol 81(9): 1475-1485

Paredes C, Cegarra J, Roig A, Sanchez-Monedero MA, Bernal MP (1999) Characterization of olive mill wastewater (alpechin) and its sludge for agricultural purposes. Biores Technol 67(2):111-115

Payne RW, Lane PW, Digby PGN, Harding SA, Leech PK, Morgan GW, Simpson HR, Todd PJ, Verrier AD, White RP (1987) Genstat 5 reference manual. UK Numerical Algorithms Group

Piotrowska A, Iamarino G, Rao MA, Gianfreda L (2006) Short-term effects of olive mill waste water (OMW) on chemical and biochemical properties of a semi-arid Mediterranean soil. Soil Biol Biochem 38(3):600-610

Ramos-Cormenzana A, Juarez-Jimenez B, Garcia-Pareja MP (1996) Antimicrobial activity of olive mill wastewaters (alpechin) and biotransformed olive oil mill wastewater. Int Biodeterior Biodegradation 38(3-4):283-290

S'habou, R., Zairi, M., Kallel, A., Aydi, A., \& Dhia, H. B. (2009) Assessing the effect of an olive mill wastewater evaporation pond in Sousse. Tunisia Environ geol 58(3):679

Saadi I, Raviv M, Berkovich S, Hanan A, Aviani I, Laor Y (2013) Fate of soil-applied olive mill wastewater and potential phytotoxicity assessed by two bioassay methods. J Environ Qual 42(6): 1791-1801

Sahraoui H, Kanzari S, Hachicha M, Mellouli HJ (2014) Olive mill effluent spreading effects on water retention of tunisian sandy loam soil. Walailak J Sci Technol (WJST) 11(1):51-62

Sciarria TP, Tenca A, D'Epifanio A, Mecheri B, Merlino G, Barbato M, Adani F (2013) Using olive mill wastewater to improve performance in producing electricity from domestic wastewater by using single-chamber microbial fuel cell. Biores Technol 147:246-253

SPSS Inc. (1988) Spss User's Guide, 2nd edn. McGraw-Hill, New York

Takriti, S. Al-kaid A., and Ibrahem S. (2009). Radiation processing of the olive-press waste waters for detoxifying the water from organic pollutants. Atomic Energy Commission, report AECS NEIRSS 818. Damascus: Syria. (in Arabic)

Tepper EZ, Shilnikova VK, Pereverzev GI (1987) Practical of microbiology, 3rd edn. Moskow, Kolas, p 239

Tomati U, Galli E, Pasetti L, Volterra E (1995) Bioremediation of olive-mill wastewaters by composting. Waste Manage Res 13(5):509-518

Tushan H, Kour H, Nehme M, Sharabati Q (2010) Effect of OMWW on the density of some microorganisms of soil cultivated with chickpea (Cicer arietimum L.). Arab J Arid Environ 5(1):77-69 ((in Arabic))

Zema DA, Lucas-Borja ME, Andiloro S, Tamburino V, Zimbone SM (2019) Short-term effects of olive mill wastewater application on the hydrological and physico-chemical properties of a loamy soil. Agric Water Manag 221:312-321

Zenjari B, El Hajjouji H, Ait Baddi G, Bailly JR, Revel JC, Nejmeddine A, Hafidi M (2006) Eliminating toxic compounds by composting olive mill wastewater-straw mixtures. J Hazard Mater 13:433-437

Zouari N, Ellouz R (1996) Microbial consortia for the aerobic degradation of aromatic compounds in olive oil mill effluent. J Ind Microbiol 16(3):155-162 